Journal of Social Sciences (COES\&RJ-JSS)

ISSN (E): 2305-9249 ISSN (P): 2305-9494

Publisher: Centre of Excellence for Scientific \& Research Journalism, COES\&RJ LLC

Online Publication Date: $1^{\text {st }}$ January 2017

Online Issue: Volume 6, Number 1, January 2017

http://centreofexcellence.net/J/JSS/JSS\%20Mainpage.htm

\title{
The Importance of (COSO-ERM) Model Implementation in Enhancing the Effectiveness of Internal Control Systems in the Jordanian Commercial Banks (Field Study)
}

\author{
Dr.Abdulsattar A.jabbar Alkubaisi \\ Associate Professor \\ Department of Accounting \\ World Islamic Sciences \& Education University \\ Amman-Jordan
}

\begin{abstract}
:
This study aimed to investigate the Importance of Committee of Sponsoring Organizations (COSO) Model for Enterprise risks management (ERM) Implementation in Enhancing the Effectiveness of Internal Control Systems in the Jordanian Commercial Banks. To achieve this goal a questionnaire was designed and distributed to a random sample of (65) respondents including financial managers, audit managers, internal auditors, and department of IT. (58) Questionnaires were valid for analysis at rate of (89\%). The study population consists of all commercial banks in Jordan (13). The study hypotheses were tested using the descriptive and analytical approach. The findings showed a high level evaluation according to study sample point of view towards the importance of (COSOERM) Model Implementation in Enhancing the Effectiveness of Internal Control Systems in the Jordanian Commercial Banks. Certain differences in details of component evaluation, Enterprise risk management came first in ranking; followed by events identification; internal control environment, objective setting; information and communication; risk assessment; monitoring; risk response, and control activities. The study recommends banks management to give more attention for continuous improvement to their internal control and accounting systems, to keep up with Business environment improvement especially the continuous follow-up of the concerned activities, and arming the staff in various jobs and levels with necessary educations and skills.
\end{abstract}

Keywords:

Internal control system, COSO-ERM model

\section{Citation:}

Alkubaisi, Dr. Abdulsattar A. Jabbar (2017); The Importance of (COSO-ERM) Model Implementation in Enhancing the Effectiveness of Internal Control Systems in the Jordanian Commercial Banks (Field Study) ; Journal of Social Sciences (COES\&RJ-JSS), Vol.6, No.1, pp: 156-177. 


\section{Introduction}

The world has known the control since ancient times and has evolved in its aims, structures, themes and functions, whether in respect of institutions or countries, and will remain in constant evolution because it will continue to be subjected to criticism as long as it comes to seeking the best use of available resources. Perhaps today there is a need to more effective control systems to address the cases of fraud and collapse accompanying major international and domestic companies and led to a loss of investor confidence, where the relationship transferred from a relationship of trust to another dominated by crises of confidence. So the internal control systems represents the safety valve to ensure that the economic unit operates according to the laws, policies and procedures adopted with a high level of efficiency and effectiveness in performance, assets protection against misuse, and make adequate care towards risks. Because commercial banks in Jordan do not differ in conditions as other economic units in the world in terms of the risks mentioned, This study came to test The Importance of (COSO-ERM) Model Implementation in Enhancing the Effectiveness of Internal Control Systems in the Jordanian Commercial Banks.

\section{Problem of the Study}

Economic units facing many problems as a result of their internal control systems weakness, due to Unavailability of the basic components, career inflation, unsound organizational structure, duplication and Power overlap, lack of clarity of plans, and weak of accountability with formal role of board of directors, Which requires the implementing of an effective internal control systems to achieve the accuracy and reliability of financial reporting, encourage commitment policies and laws, and to achieve efficiency and effectiveness of operational activities, So this study tries to answer if (COSO-ERM) model for enterprise risks management adoption, Is important to enhancing the effectiveness of internal control systems in the Jordanian commercial banks?

\section{Study Importance}

Because (COSO-ERM) model for enterprise risks management, establishes to a high effectiveness of internal control systems, for its positive role on decision making in banks, especially to those related to credit and investment, So the importance of the study come from the evaluating to which level that the Implementation of this Model Enhancing the Effectiveness of Internal Control Systems in the Jordanian Commercial Banks.

\section{Procedural Definitions and Theoretical Framework of the Study}

- Internal control: Committee of Sponsoring Organization of the Trade Way Commission (COSO), defined the internal control as a process designed and influenced by management, and by which it can obtain reasonable assurance that the objectives be achieved, credibility of financial statements, effectiveness of operational operations, compliance with policies, laws and regulations.

- Commission (COSO): The Committee of Sponsoring Organizations (COSO) formed from the American Institute of Certified Public Accountants (AICPA), Financial Executives Institute (FEI), the Institute of Internal Auditors (IIA), the American Association of Accountants (AAA), And the Institute of Management Accountants (IMA). In 1992 (COSO) Organization issued a framework of integrated internal control, which is meant to provide guidance to assess and strengthen control systems, which form an acceptable reference for companies in the designing of policies, laws, and regulations used 
to adjust work activities as well as the acceptance by government legislation, including the law (SOX) of 2002.

\section{- $\quad$ Enterprise risk management (ERM)}

The Committee of Sponsoring Organizations of the Trade way Commission (COSO) defined (ERM) as a process, effected by an entity's board of directors, management and other personnel, applied in a strategy setting and across the enterprise, designed to identify potential events that may affect the entity, and manage risk to be within its risk appetite, to provide reasonable assurance regarding the achievement of entity objectives. The ERM framework is geared to achieving an organization's objectives, set forth in the following four categories:

1. Strategic, High-level goals, aligned with and supporting its mission.

2. Operations, Effective and efficient use of its resources.

3. Reporting, Reliability of reporting.

4. Compliance, Compliance with applicable laws and regulations.

\section{- COSO- ERM framework}

It consists of eight interrelated components:

1. Internal environment, The internal environment sets the foundation for how risk is viewed and addressed by an organization's people, including risk philosophy; risk appetite; integrity and ethical values; and the environment in which it operate.

2. Objective setting, Objectives must exist before management can identify potential risks affecting their achievement. ERM ensures that management has in place a process to set objectives and that the chosen objectives support and align with the entity's mission and are consistent with its risk appetite.

3. Event identification, Internal and external events affecting the achievement of an organization's objectives must be identified, distinguishing between risks and opportunities.

4. Risk assessment, Risks are analyzed, considering likelihood and impact, as a basis for how they should be managed. Risks are assessed on an inherent and residual basis.

5. Risk response, Management selects risk responses-avoiding, accepting, reducing, or sharing risk-developing a set of actions to align risks with the organization's risk tolerances and risk appetite.

6. Control activities, Policies and procedures are established and implemented to help ensure the risk responses are effectively carried out.

7. Information and communication, Relevant information is identified, captured, and communicated in a form and time frame that enables people to carry out their responsibilities. Effective communication also occurs in a broader sense, flowing down, across, and up the organization.

8. Monitoring. The entire ERM process is monitored and modifications are made as necessary. Monitoring is accomplished through ongoing management activities, separate evaluations, or both.

\section{Literature Review}

(1) Al- Hanini study (2015), This study aimed to evaluate the reliability of the internal control methods on the computerized information systems in banks operating in Jordan. A questionnaire was designed and distributed to the random sample of the study which consisted of 50 respondents of the managers and the employees of the computer units and the branches' managers and the financial managers in the banks operating in Jordan. After 
using the Statistical Package (SPSS), it was concluded that the methods of the internal control used in the banks operating in Jordan were reliable because they met the requirements of the availability principle of the system; they adopted policies and control and precautionary procedures to reduce the system's downtime as possible , they met the requirements of the security principle of the system through the protection against the physical and logical access and the protection of the personal computers and the networks. and they also met the requirements of the principle of the maintenance and the adjustment in terms of the existence of a strategic plan of maintenance, periodic evaluation of the system, and the use of the proper procedures of documentations and finally they met the requirements of integration where the banks adopted control procedures on the sources of data, the input, the processes, the outputs and the transfer operations. The most important recommendation of the study concentrate on raising the employees' awareness of the importance of the control procedures and their goals before being trained to follow them.

(2) Ghosh study (2013), This study aimed to test the effect of applying (ERM) framework for project risks management (setting goals, identifying events, Risk assessment, and risk response) in creating value at Indian companies, in addition to identifying the determinants and constraints of applying this framework. The study applied on 100 companies listed on the Indian stock market, and for the purpose of achieving its objectives a Questionnaire was distributed to the CFOs, risk managers, and internal auditors. The results indicates that companies with high-volume, high-profit and complex operations prefer adopting (ERM) framework for the managing its internal and external risk more than small-sized companies. The results also indicate that adopting (ERM) framework for project risks management affect positively in creating value for companies through the ability to cope with risk, and get Competitive advantages, reduce stock prices fluctuation and reduce its costs. The study recommended the need to increase the participation of Board of Directors and improve its supervisor role in mentoring risk process in that companies.

(3) Scannell et al study (2013), the study aimed to examine how companies identify and manage supply chain risks and how those actions relate to systemic enterprise risk management (ERM). To achieve this goal, Data from 46 companies at the United States of America were analyzed to identify which factors affect the decision to develop a supply chain risk management (SCRM) system and how the resultant systems compare to an ERM system. The study concluded that project risk management system components (ERM) of (COSO) 2004 Provides a reasonable framework which enables companies to achieve integration between the (ERM) system and supply chain risk management (SCRM) system. The study recommended the need to link risk management system with supply chain risk management system at companies to develop their strategies.

(4) Barakat study (2009), the study aimed at investigating the degree of application of Basel's committee requirements by Jordan banks. A questionnaire was developed and distributed over 40 subjects from all commercial banks in Jordan, the data was analyzed by using Statistical Package for Social Sciences (SPSS). The results revealed that all banks in Jordan are applying Basel's II norms. Results do not reveal any significant difference on the extent of implementing Basel II committee resolutions. It seems that availability of internal control systems and providing the same with work freedom shall not be limited only to Jordan banks but the existence of Arab, and foreign banks in Jordan. Moreover the results revealed that there were significant differences in application of 
Basel's II norms between local banks and foreign banks. To manage risks, the executive management needs periodical evaluations of followed procedures, its appropriateness, the availability of managerial authorities, efficient human resources and management of fruitful discourse to enhance internal control system. The study recommends the need to test bank loans and foreign credit companies, and not rely solely on the internal control operations in granting the loans.

(5) Rittenberg study (2006), which aimed to clarify the role of Internal Control Standards guidelines in preparing the financial statements for small-sized public companies, which Issued by the Commission (COSO) in 2006 in response to the request of the US Securities Exchange to help small-sized public companies in the approval of the financial reports to Section 404 requirements of the Sarbanes-Oxley Committee for the year 2002, the study concluded that despite of the fact that the new standard does not modify or alter the original standard documents, but it covers the challenges facing small-sized businesses to the new standard guidance includes three sections each with a specific goal, the first overviews the senior management and other committees, the second goal presents practical guidance with practical examples of small businesses, and the third goal Provides evaluation tools to help organizations to implement and evaluate the internal control systems with regard to financial statements preparation.

\section{Contribution of the Study}

A part of previous studies focused on the analysis of internal control systems in terms of styles, applications, objectives and their impact on enterprise performance, another part focused on the structures of internal control systems and certain components impacts according to (COSO) model or SOX Act, a third part of researches have studied the framework $(E R M)$ for the management of enterprise risk separately from the mentioned model (COSO). This study is characterized by evaluating the internal control systems at a different environment, with taking in the consideration all the eight components of the (COSO-ERM) model In order to test their importance in Enhancing the Effectiveness of Internal Control Systems in the Jordanian Commercial Banks.

\section{Methodology of the Study}

To realize the study objective, a descriptive analytical approach was used in collecting and analyzing data, for this purpose a questionnaire includes the eight components of the mentioned model (COSO) were designed. The methodology of the study recovers:

a. population and sample

The study population consisted of Jordanian commercial banks (13) banks, while the study sample encompassing the CFOs, directors of internal audit, internal auditors, directors of risk management, engineers at Computer center) in these banks. The questionnaires were distributed to a random sample at a rate of (5) questionnaires for each bank, where the number of distributed questionnaires was (65). Then (58) questionnaire was recovered and valid for analysis in rate of (89\%).

b. data sources

The study is based on two types of data sources, secondary sources which represented in books, periodicals, reports and publications related to the subject of the study, Primary sources which consisted mainly through the questionnaire prepared for this purpose and were designed in two parts as follows:

Part I: A letter addressed to the study sample which illustrates the scope and the study objectives, as well as private data of the sample (such as specialty and years of experience), as follows: 
The Importance of (COSO-ERM) Model Implementation .......

Table (1): study sample qualification

\begin{tabular}{|l|l|l|l|}
\hline Variable & Class & No. & Percentage \\
\hline \multirow{4}{*}{$\begin{array}{l}\text { Educational } \\
\text { qualification }\end{array}$} & B.A & 36 & 62.07 \\
\cline { 2 - 4 } & Master & 15 & 62.07 \\
\cline { 2 - 4 } & PHD. & 5 & 8.62 \\
\cline { 2 - 4 } & Others & 2 & 3.45 \\
\cline { 2 - 4 } & Total & 58 & 100.00 \\
\hline \multirow{4}{*}{ certificates } & CIA & 17 & 29.31 \\
\cline { 2 - 4 } & CPA & 20 & 34.48 \\
\cline { 2 - 4 } & CMA & 19 & 32.76 \\
\cline { 2 - 4 } & JCPA & 19 & 32.76 \\
\cline { 2 - 4 } & Other & 9 & 15.52 \\
\hline \multirow{4}{*}{ Experience } & Less than 5 years & 4 & 6.90 \\
\cline { 2 - 4 } & From 5 years to less than 10 years & 13 & 22.41 \\
\cline { 2 - 4 } & From 10 years to less than 15 years & 19 & 32.76 \\
\cline { 2 - 4 } & From 15 years to less than 20years & 10 & 17.24 \\
\cline { 2 - 4 } & From 20 years and more & 12 & 20.69 \\
\cline { 2 - 4 } & Total & 58 & 100.00 \\
\hline \multirow{5}{*}{ Courses } & Managing risks in banks & 42 & 72.41 \\
\cline { 2 - 4 } & $\begin{array}{l}\text { COSO Commission Decisions and } \\
\text { its relation to banking risks }\end{array}$ & 30 & 51.72 \\
\cline { 2 - 4 } & $\begin{array}{l}\text { Risk assessment And its necessary } \\
\text { solutions }\end{array}$ & 19 & 32.76 \\
\hline
\end{tabular}

The table above indicates:

- The proportion of $(62 \%)$ of the study sample was from those who have a preliminary (B.A) degree, which means that the study population was scientifically qualified to answer the study questions.

- The proportion of $(70.34 \%)$ of the study sample have an experience in banking business for more than 10 years, which means that the sample has a great practical experience enabling them to answer the study questions.

- The majority of the study sample obtains professional certificates of accounting and auditing, which gives them additional capacity to answer the questionnaire with the quality required.

- Most of the study sample was from those who have received training in the field of banking risk management and decisions of COSO Commission and its relationship to banking risks.

Part II: The sample respondent's answers will be measured according to the Likert ladder. c. statistical methods used

By using (SPSS), the appropriate statistical methods for data analyzing and hypotheses testing were:

- Measures of central tendency, such as the mean variance and frequencies, percentages, to describe the study sample opinions about the variables of the study and to determine the importance of the statements in the questionnaire, as well as the use of the standard deviation to describe the dispersion extent of the answers from their means. 
- Cronbach's alpha test, and Spearman-Brown test were used, in order to test the stability of questionnaire paragraphs.

- $\quad$ T-test for one sample (T-Test) to find out if the response average had reached a middle class which is 3 or augmented or diminished it. All of this has been done.

\section{d. test the validity and reliability of the instrument}

Validity and reliability study tool were confirmed in two ways:

- $\quad$ To ensure the validity, and in order to detect the ability of its data to achieve the desired goals, and to clarify the drafting phrases, and the suitability of each phrase of the axis which they belong to, the study tool was distributed in its primary form to a group of judges consisted of (8) members from the Jordanian universities faculty members who has qualification and experience accounting and Statistics fields,

- Cronbach's alpha method was used for measuring the stability of the questionnaire, and as shown in Table (2) in the areas of internal control systems assessment in the Jordanian commercial banks, according to the (COSO-ERM) model for project risks management, the internal consistency has high degrees, where ranging between 0.904 stability in the area of responding to the risks and 0.730 for the goals identification, it was 0.943 for whole the questionnaire, all values were sufficient values to achieve the purpose for the study.

Table (2) Cronbach's alpha coefficient to measure the stability of the questionnaire

\begin{tabular}{|l|l|l|l|}
\hline No. & Field & $\begin{array}{l}\text { No. } \\
\text { paragraph }\end{array}$ & $\begin{array}{l}\text { Cronbach's } \\
\text { alpha value }\end{array}$ \\
\hline $\mathbf{1}$ & Internal control Environment & 10 & 0.765 \\
\hline $\mathbf{2}$ & Objective Setting & 8 & 0.730 \\
\hline $\mathbf{3}$ & Event Identification & 2 & 0.786 \\
\hline $\mathbf{4}$ & Risk Assessment & 8 & 0.781 \\
\hline $\mathbf{5}$ & Risk Response & 3 & 0.904 \\
\hline $\mathbf{6}$ & Control Activities & 13 & 0.899 \\
\hline $\mathbf{7}$ & Information \& Communications & 13 & 0.821 \\
\hline $\mathbf{8}$ & Monitoring & 7 & 0.731 \\
\hline \multicolumn{2}{|c|}{ Total } & $\mathbf{6 4}$ & $\mathbf{0 . 9 4 3}$ \\
\hline
\end{tabular}

\section{Study Hypotheses}

According to the problem's question, the Main Hypothesis (H0) can be formed:"No importance to the (COSO-ERM) model implementation in enhancing the effectiveness of internal control systems in the Jordanian Commercial Banks", and from this hypothesis come the following sub-hypotheses:

H01. "No importance to the internal control environment as one of (COSO-ERM) model components in enhancing the effectiveness of internal control systems in the Jordanian commercial banks".

H02. "No importance to the objective setting as one of (COSO-ERM) model components in enhancing the effectiveness of internal control systems in the Jordanian commercial banks".

H03. No importance to the event identification as one of (COSO-ERM) model components in enhancing the effectiveness of internal control systems in the Jordanian commercial banks". 
H04. No importance to the risk assessment as one of (COSO-ERM) model components in enhancing the effectiveness of internal control systems in the Jordanian commercial banks".

H05. No importance to the risk response as one of (COSO-ERM) model components in enhancing the effectiveness of internal control systems in the Jordanian commercial banks".

H06. No importance to the control activities as one of (COSO-ERM) model components in enhancing the effectiveness of internal control systems in the Jordanian commercial banks".

H07. No importance to the information and communications as one of (COSO-ERM) model components in enhancing the effectiveness of internal control systems in the Jordanian commercial banks".

H08. No importance to the monitoring as one of (COSO-ERM) model components in enhancing the effectiveness of internal control systems in the Jordanian commercial banks".

Hypotheses Testing and Discussing the Study Results

One-sample T-test was used to test the study (main hypothesis and sub-hypotheses) associated, where the following tables show the results of testing these hypotheses:

H0 Testing: The following table shows the statistical details of this hypothesis:

Table (3): t-test results of the importance to the (COSO-ERM) model implementation in enhancing the effectiveness of internal control systems in the Jordanian Commercial Banks

\begin{tabular}{|l|l|l|l|l|l|}
\hline Variable & mean & $\begin{array}{l}\text { standard } \\
\text { deviation }\end{array}$ & $\begin{array}{l}\text { T. } \\
\text { value }\end{array}$ & $\begin{array}{l}\text { Level of } \\
\text { significance }\end{array}$ & Decision \\
\hline $\begin{array}{l}\text { internal control } \\
\text { systems } \\
\text { according to (COSO- } \\
\text { ERM) } \\
\text { model }\end{array}$ & 4.37 & 0.32 & 32.55 & 0.000 & Rejected \\
\hline
\end{tabular}

The table above shows that the arithmetic mean value of the importance to the (COSOERM) model implementation in enhancing the effectiveness of internal control systems in the Jordanian Commercial Banks reached (4.37) with standard deviation of (0.32). this means that the estimates of the study sample clearly indicate that there is a great conviction about that importance, where the average value of the sample answers came higher than the hypothetical average of the study estimated at value (3), according to Likert ladder, T. value was (32.55), at the level of significance (0.000), which is less than the expected error degree of the study (0.05), so we rejects the null hypothesis of the study, and accept the alternative hypothesis, which states: "There is an importance to the (COSO-ERM) model implementation in enhancing the effectiveness of internal control systems in the Jordanian Commercial Banks".

H01 Testing: The following table shows the statistical details of this hypothesis:

Table (4): T-test results of the importance to the internal control environment as one of (COSO-ERM) model components in enhancing the effectiveness of internal control systems in the Jordanian commercial banks 


\begin{tabular}{|l|l|l|l|l|l|}
\hline Variable & $\begin{array}{l}\text { Mea } \\
\mathbf{n}\end{array}$ & $\begin{array}{l}\text { standard } \\
\text { deviation }\end{array}$ & $\begin{array}{l}\mathbf{t} \\
\text { valu } \\
\text { e }\end{array}$ & $\begin{array}{l}\text { Level of } \\
\text { significance }\end{array}$ & Decision \\
\hline $\begin{array}{l}\text { Internal control } \\
\text { Environment }\end{array}$ & 4.46 & 0.35 & $\begin{array}{l}32.1 \\
1\end{array}$ & 0.000 & Rejected \\
\hline
\end{tabular}

The table (4) indicates that the arithmetic mean value of internal control environment has reached a value of (4.46) and standard deviation (0.35) and this clearly shows the great importance to the internal control environment as one of (COSO-ERM) model components in enhancing the effectiveness of internal control systems in the Jordanian commercial banks. the $t$ value was (32.11) at level of significance( 0.000$)$, so we rejects the null hypothesis of the study, and accept the alternative hypothesis which states: "There is an importance to the internal control environment as one of (COSO-ERM) model components in enhancing the effectiveness of internal control systems in the Jordanian commercial banks".

H02 Testing: The following table explains the results of this hypothesis:

Table (5) t-test results of the importance to the objective setting as one of (COSO-ERM) model components in enhancing the effectiveness of internal control systems in the Jordanian commercial banks

\begin{tabular}{|l|l|l|l|l|l|}
\hline Variable & Mean & $\begin{array}{l}\text { standard } \\
\text { deviation }\end{array}$ & $\begin{array}{l}\text { T } \\
\text { value }\end{array}$ & $\begin{array}{l}\text { Level of } \\
\text { significance }\end{array}$ & Decision \\
\hline Objective Setting & 4.38 & 0.50 & 20.98 & 0.000 & Rejected \\
\hline
\end{tabular}

The table indicates that the arithmetic mean value of the variable objectives setting reached (4.38) with a standard deviation of (0.50), the mean value of the study sample estimates indicates clearly their belief in the importance of objective setting in the importance to the objective setting as one of (COSO-ERM) model components in enhancing the effectiveness of internal control systems in the Jordanian commercial banks, the t value was (20.98) at level of significance (0.000) and where the significance level value less than 0.05 , so we rejects the null hypothesis of the study and accept the alternative hypothesis which states: "There is an importance to the objective setting as one of (COSO-ERM) model components in enhancing the effectiveness of internal control systems in the Jordanian commercial banks ".

H03 Testing: The following table shows the results of this hypothesis:

Table (6) t-test results for the importance of Event Identification as one of (COSOERM) model components in enhancing the effectiveness of internal control systems in the Jordanian commercial banks

\begin{tabular}{|l|l|l|l|l|l|}
\hline Variable & mean & $\begin{array}{l}\text { standard } \\
\text { deviation }\end{array}$ & $\begin{array}{l}\text { T } \\
\text { value }\end{array}$ & $\begin{array}{l}\text { Level of } \\
\text { significance }\end{array}$ & Decision \\
\hline Event Identification & 4.50 & 0.43 & 26.61 & 0.000 & Rejected \\
\hline
\end{tabular}

The table (6) indicates that the arithmetic mean value of event identification has reached (4.50) with a standard deviation (0.43), the mean value of the study sample estimates clearly indicate the importance of event identification as one of (COSO-ERM) model components in enhancing the effectiveness of internal control systems in the Jordanian commercial banks. The value of $t$ was (26.61) at level of significance (0.000) and where it 
is less than 0.05 , so we rejects the null hypothesis and accept the alternative hypothesis which states: "There is importance to the event identification as one of (COSO-ERM) model components in enhancing the effectiveness of internal control systems in the Jordanian commercial banks".

H04 Testing: The following table shows The results of this hypothesis:

Table (7): t-test results for the importance of risk assessment as one of (COSO-ERM) model components in enhancing the effectiveness of internal control systems in the Jordanian commercial banks

\begin{tabular}{|l|l|l|l|l|l|}
\hline Variable & Mean & $\begin{array}{l}\text { standard } \\
\text { deviation }\end{array}$ & $\begin{array}{l}\text { T } \\
\text { value }\end{array}$ & $\begin{array}{l}\text { Level of } \\
\text { significance }\end{array}$ & Decision \\
\hline Risk Assessment & 4.36 & 0.42 & 24.65 & 0.000 & Rejected \\
\hline
\end{tabular}

The table number(7) indicates that the arithmetic mean value of risk assessment has reached (4.36) with a standard deviation (0.42), the mean value of the study sample estimates clearly indicate their belief in the importance of risk assessment as one of (COSO-ERM) model components in enhancing the effectiveness of internal control systems in the Jordanian commercial banks. The $t$ value was (24.65) at level of significance (0.000), so we reject the null hypothesis and accept the alternative one which states: "There is an importance to the risk assessment as one of (COSO-ERM) model components in enhancing the effectiveness of internal control systems in the Jordanian commercial banks".

H05 Testing: The following table shows the results of this hypothesis:

Table (8): $t$-test results for the importance of risk response as one of (COSO-ERM) model components in enhancing the effectiveness of internal control systems in the Jordanian commercial banks

\begin{tabular}{|l|l|l|l|l|l|}
\hline Variable & mean & $\begin{array}{l}\text { standard } \\
\text { deviation }\end{array}$ & $\begin{array}{l}\text { T } \\
\text { value }\end{array}$ & $\begin{array}{l}\text { Level of } \\
\text { significance }\end{array}$ & Decision \\
\hline Risk Response & 4.31 & 0.61 & 16.32 & 0.000 & Rejected \\
\hline
\end{tabular}

The above table indicates that the arithmetic mean value of risk response has reached (4.31) with standard deviation (0.61), the mean value of the study sample estimates clearly indicate their belief in the importance of risk response as one of (COSO-ERM) model components in enhancing the effectiveness of internal control systems in the Jordanian commercial banks. The t value was (16.32) at level of significance $(0.000)$ and the significance level value was less than 0.05 , so we reject the null hypothesis and accept the alternative hypothesis which states: "There is an importance to the risk response as one of (COSO-ERM) model components in enhancing the effectiveness of internal control systems in the Jordanian commercial banks".

H06 Testing: The following table shows the results of this hypothesis:

Table ( 9 t-test results for the importance of control activities as one of (COSO-ERM) model components in enhancing the effectiveness of internal control systems in the Jordanian commercial banks 


\begin{tabular}{|l|l|l|l|l|l|}
\hline Variable & Mean & $\begin{array}{l}\text { standard } \\
\text { deviation }\end{array}$ & $\begin{array}{l}\text { t } \\
\text { value }\end{array}$ & $\begin{array}{l}\text { Level of } \\
\text { significance }\end{array}$ & Decision \\
\hline $\begin{array}{l}\text { Control } \\
\text { Activities }\end{array}$ & 4.28 & 0.55 & 17.84 & 0.000 & Rejected \\
\hline
\end{tabular}

The table (9) indicates that arithmetic mean value of the control activities has reached (4.28) with standard deviation (0.55), the mean value of the study sample estimates clearly indicate their belief in the importance of control activities as one of (COSO-ERM) model components in enhancing the effectiveness of internal control systems in the Jordanian commercial banks. The t value was(17.84) at level of significance (0.000) and the significance level value was less than 0.05 , so we reject the null hypothesis and accept the alternative hypothesis which states: "There is an importance to the control activities as one of (COSO-ERM) model components in enhancing the effectiveness of internal control systems in the Jordanian commercial banks".

H07 Testing: The following table shows the results of this hypothesis:

Table (10): $t$-test results for the importance of information and communications as one of (COSO-ERM) model components in enhancing the effectiveness of internal control systems in the Jordanian commercial banks

\begin{tabular}{|l|l|l|l|l|l|}
\hline Variable & mean & $\begin{array}{l}\text { standard } \\
\text { deviation }\end{array}$ & $\begin{array}{l}\text { T } \\
\text { value }\end{array}$ & $\begin{array}{l}\text { Level of } \\
\text { significanc } \\
\text { e }\end{array}$ & Decision \\
\hline $\begin{array}{l}\text { Information } \\
\text { Communications }\end{array}$ & 4.37 & 0.41 & 25.54 & 0.000 & Rejected \\
\hline
\end{tabular}

The above table indicates that the arithmetic mean value of information and communication has reached (4.37) with standard deviation (0.41), the mean value of the study sample estimates clearly indicate their belief in the importance of information and communication as one of (COSO-ERM) model components in enhancing the effectiveness of internal control systems in the Jordanian commercial banks. The $t$ value was (25.54) at level of significance (0.000) and the significance level value was less than 0.05 , so we reject the null hypothesis and accept the alternative hypothesis which states: "There is an importance to the information and communication as one of (COSO-ERM) model components in enhancing the effectiveness of internal control systems in the Jordanian commercial banks".

H08 Testing: The following table shows the results of this hypothesis:

Table (11): $t$-test results for the importance of monitoring as one of (COSO-ERM) model components in enhancing the effectiveness of internal control systems in the Jordanian commercial banks

\begin{tabular}{|l|l|l|l|l|l|}
\hline Variable & Mean & $\begin{array}{l}\text { standard } \\
\text { deviation }\end{array}$ & $\begin{array}{l}\mathbf{t} \\
\text { value }\end{array}$ & $\begin{array}{l}\text { Level of } \\
\text { significance }\end{array}$ & Decision \\
\hline Monitoring & 4.35 & 0.43 & 24.10 & 0.000 & Rejected \\
\hline
\end{tabular}

The above table indicates that the arithmetic mean of monitoring has reached (4.35) with standard deviation (0.43), the mean value of the study sample estimates clearly indicate their belief in the importance of monitoring as one of (COSO-ERM) model components 
in enhancing the effectiveness of internal control systems in the Jordanian commercial banks. The $t$ value was $(24.10)$ at level of significance $(0.000)$ and the significance level value was less than 0.05 , so we reject the null hypothesis and accept the alternative hypothesis which states: "There is an importance to the monitoring as one of (COSO-ERM) model components in enhancing the effectiveness of internal control systems in the Jordanian commercial banks".

\section{Conclusions}

1- Generally, all (COSO-ERM) model components revealed playing big and important role in the effectiveness enhancing of the internal control systems in Jordanian commercial banks, which reached at $87 \%$, but although of this god result the studied commercial banks must try to treat the deviation of $13 \%$ which can be translated from other side by waste at same rate in the bank resources.

2- In details:

- There is a difference of $5 \%$ between lowest and highest value, which also means that the lowest value reach to $15 \%$ in term of diminishing in internal control effectiveness.

- The biggest standard deviation of the study sample is 0.61 which reflect that the sample be more dissimilar to risk response, while the sample is more similar in the case of control environment importance in enhancing the internal control effectiveness of that banks.

- The differences of deviations at the level of each internal control component, is clearly fluctuated by comparison with means, they are $42 \%$ for control environment; $33 \%$ objective setting; $13 \%$ event identification; $31 \%$ risk assessment; $22 \%$ risk response; $34 \%$ control activities; $39 \%$ information and communications; and 32\% monitoring

\section{Recommendations}

Based on the conclusions, this study recommends the following:

1- Need to arm all individuals in all administrative jobs with necessary skills and qualifications, to ensure their relevant participation in rising the role of all internal control components at same level, in the enhancing of its effectiveness, because internal control process is affected by employees and affect them.

2- Developing the application process of all internal components beginning with less situation in the effectiveness enhancing, ending with this have biggest role, that is because all mentioned components take the same importance in objectives realization.

3- Need to develop more research in this area, especially on the efficiency domain to obtain a clear portrait needed for best performance in those banks.

\section{References}

1- Ahmad Rizal Razali, \& Izah Mohammed Tahir(2011), Review of the Literature on Enterprise/Risk Management, Business Management Dynamics, Vol.1, No.5, Nov,pp816.

2- Al-Hanini, Eman(2015),Evaluating the Reliability of the Internal Control on the Computerized Accounting Information Systems: An Empirical Study on Banks Operating in Jordan", Research Journal of Finance and Accounting ,Vol.6, No.8, 2015, Pp 176186

3- Ayagre, Philip (2014), The effectiveness of Internal Control Systems of banks: The case of Ghanaian banks, International Journal of Accounting and Financial Reporting Vol. 4, No. 2 , pp 377- 389 
4- Barakat, Abdullah.(2009), Banks II norms requirement regarding internal control, Field study on Jordan Banks, Delhi Business Review, Vol. 10, No. 2,pp 35-48. Ghosh, Arpit.(2013), An Empirical Investigation into Enterprise Risk Management in India, Indian Accounting Review Indian Accounting Association Research Foundation, 17 (1), June 2013, pp 1- 25.

5- Basel committee. BBC (2012, December 11). http://www.bbc.com/news/business20673466

6- Ghosh, Arpit.(2013), An Empirical Investigation into Enterprise Risk Management in India, Indian Accounting Review Indian Accounting Association Research Foundation, 17 (1), June 2013, pp 1- 25.

7- IFAC. (2012). Final Pronouncement: June, Evaluating and Improving Internal Control in Organizations: $\mathrm{http} / / / \mathrm{www}$.ifac.org.

8- INTOSAI. (2004). Guidelines for internal control standards for the public sector. http://www.intosai.org

9- Rittenberg, Larry E (2006), INTERNAL CONTROL: NO SMALL MATTER, The internal Control, Vo. 63, No.5, Pp.47-52.

10- Romney, Marshal B.\& Steinbart Paul J.(2009), Accounting Information Systems, PEARSON, 12 edition, 2012.

11- Thomas, Scannell, Sime Curkovic, Bret J. Wagner \& Michael J.V. (2013), Supply chain Risk Management within the context of COSO's Enterprise Management Framework, Journal of Business Administration Research, Vol. 2, No. 1.pp 15- 28.

Sites

- http://www.upet.ro/annals/economics/pdf/2011/Njanike-Mutengezanwa-Gombarume.pdf

- http://project2005-07.ia-manager.org/files/Summary_of_IFCA_Principles.pdf

- $\quad$ https://www.coso.org/Pages/default.aspx

\section{Appendix}

Table(12): Means, standard deviation for Internal control Environment Component COSO- ERM model (in descending order) 


\begin{tabular}{|c|c|c|c|c|c|c|}
\hline No. & Paragraph & $\begin{array}{l}\text { Mea } \\
\text { n }\end{array}$ & $\begin{array}{l}\text { Importan } \\
\text { ce } \\
\%\end{array}$ & $\begin{array}{l}\text { Standar } \\
\text { d } \\
\text { deviatio } \\
\text { n }\end{array}$ & $\begin{array}{l}\text { leve } \\
\text { l }\end{array}$ & $\begin{array}{l}\text { Ran } \\
k\end{array}$ \\
\hline 1 & $\begin{array}{l}\text { Philosophy of risk management in } \\
\text { the bank is a behavior and } \\
\text { confidence of a common perception } \\
\text { that the way the bank deal with risk } \\
\text { in all the work exercised starting } \\
\text { from the development of the } \\
\text { strategy through to daily work } \\
\text { activities. }\end{array}$ & 4.69 & 0.54 & 93.80 & $\begin{array}{l}\mathrm{Hig} \\
\mathrm{h}\end{array}$ & 1 \\
\hline 4 & $\begin{array}{l}\text { It must be available to the bank's } \\
\text { management full transparency for } \\
\text { the disclosure of all risks. }\end{array}$ & 4.52 & 0.66 & 90.40 & $\begin{array}{l}\text { Hig } \\
\mathrm{h}\end{array}$ & 2 \\
\hline 3 & $\begin{array}{l}\text { Must be efficient and professional } \\
\text { staff is available at the bank's risk } \\
\text { management in it. }\end{array}$ & 4.5 & 0.66 & 90.00 & $\begin{array}{l}\mathrm{Hig} \\
\mathrm{h}\end{array}$ & 3 \\
\hline 5 & $\begin{array}{l}\text { There must be a special philosophy } \\
\text { and style of management have } \\
\text { turned positive on the financial and } \\
\text { administrative tasks and auditing }\end{array}$ & 4.5 & 0.60 & 90.00 & $\begin{array}{l}\text { Hig } \\
\mathrm{h}\end{array}$ & 4 \\
\hline 2 & $\begin{array}{l}\text { Risk management philosophy affect } \\
\text { the culture and operating style, } \\
\text { including how to identify and } \\
\text { clarify the risks, and the quality of } \\
\text { acceptable risk and how to manage } \\
\text { them. }\end{array}$ & 4.48 & 0.50 & 89.60 & $\begin{array}{l}\text { Hig } \\
\mathrm{h}\end{array}$ & 5 \\
\hline 9 & $\begin{array}{l}\text { Must be contained any philosophy } \\
\text { of risk management at the bank in } \\
\text { their own policy statements, and in } \\
\text { oral and written communication } \\
\text { with the stakeholders, and } \\
\text { employees in the decision-making } \\
\text { processes. }\end{array}$ & 4.43 & 0.60 & 88.60 & $\begin{array}{l}\text { Hig } \\
\mathrm{h}\end{array}$ & 6 \\
\hline 7 & $\begin{array}{l}\text { Senior management of the bank is } \\
\text { considered an important part of the } \\
\text { internal environment and effect the } \\
\text { elements significantly }\end{array}$ & 4.41 & 0.53 & 88.20 & $\begin{array}{l}\mathrm{Hig} \\
\mathrm{h}\end{array}$ & 7 \\
\hline 10 & $\begin{array}{l}\text { Should be available in the bank's } \\
\text { system of internal tuning } \\
\text { contributes to adjust the } \\
\text { performance of employees as well } \\
\text { as well as the written rules define } \\
\text { the duties and responsibilities of the } \\
\text { bank employees }\end{array}$ & 4.4 & 0.77 & 88.00 & $\begin{array}{l}\mathrm{Hig} \\
\mathrm{h}\end{array}$ & 8 \\
\hline 6 & Organizational structure of the bank & 4.33 & 0.69 & 86.60 & & 9 \\
\hline
\end{tabular}




\begin{tabular}{|c|c|c|c|c|c|c|}
\hline & $\begin{array}{l}\text { must have a appropriate regularity } \\
\text { for the nature of the work and the } \\
\text { size of the bank. }\end{array}$ & & & & $\begin{array}{l}\text { Hig } \\
\mathrm{h}\end{array}$ & \\
\hline 8 & $\begin{array}{l}\text { Management must have a good } \\
\text { styled evolution of powers as well } \\
\text { as the existence of effective polices } \\
\text { for employment in the bank. }\end{array}$ & 4.31 & 0.68 & 86.20 & $\begin{array}{l}\text { Hig } \\
\text { h }\end{array}$ & 10 \\
\hline & Average & 4.46 & 0.35 & 89.20 & $\begin{array}{l}\text { Hig } \\
\text { h }\end{array}$ & \\
\hline
\end{tabular}

Table (13): Means, standard deviation for Objective Setting Component COSO- ERM model (in descending order)

\begin{tabular}{|c|c|c|c|c|c|c|}
\hline No. & Paragraph & $\begin{array}{l}\text { Mea } \\
\text { n }\end{array}$ & $\begin{array}{l}\text { Importanc } \\
\text { e } \\
\%\end{array}$ & $\begin{array}{l}\text { Standard } \\
\text { deviation }\end{array}$ & $\begin{array}{l}\text { leve } \\
\text { l }\end{array}$ & $\begin{array}{l}\text { Ran } \\
\mathbf{k}\end{array}$ \\
\hline 5 & $\begin{array}{l}\text { The administration should put the } \\
\text { necessary plans to achieve goals, } \\
\text { and that there is a connection } \\
\text { between the various administrative } \\
\text { levels alerted to the existence } \\
\text { of any relation to the risk of not } \\
\text { achieving those goals. }\end{array}$ & 4.53 & 0.63 & 90.60 & $\begin{array}{l}\text { Hig } \\
\mathrm{h}\end{array}$ & 1 \\
\hline 1 & $\begin{array}{l}\text { The moral values and integrity } \\
\text { of management affect the way } \\
\text { the implementation of all of the } \\
\text { strategic objectives of the bank }\end{array}$ & 4.48 & 0.88 & 89.60 & $\begin{array}{l}\text { Hig } \\
\mathrm{h}\end{array}$ & 2 \\
\hline 2 & $\begin{array}{l}\text { The general goals of the bank must } \\
\text { be specify and sub-goals on the } \\
\text { level of activity and the } \\
\text { link between them, in order } \\
\text { to identify potential risks }\end{array}$ & 4.43 & 0.70 & 88.60 & $\begin{array}{l}\text { Hig } \\
\mathrm{h}\end{array}$ & 3 \\
\hline 4 & $\begin{array}{l}\text { Identification of the Bank's } \\
\text { objectives is first step to assess } \\
\text { the risks, and is considered } \\
\text { targets as criteria used to assess the } \\
\text { administration's performance. }\end{array}$ & 4.41 & 0.68 & 88.20 & $\begin{array}{l}\text { Hig } \\
\mathrm{h}\end{array}$ & 4 \\
\hline 6 & $\begin{array}{l}\text { Strategic plans should be put in a } \\
\text { consistent manner with the overall } \\
\text { objectives of the bank. }\end{array}$ & 4.38 & 0.72 & 87.60 & $\begin{array}{l}\mathrm{Hig} \\
\mathrm{h}\end{array}$ & 5 \\
\hline 3 & $\begin{array}{l}\text { The Bank shall be communicated } \\
\text { to all employees in all of the main } \\
\text { objectives and } \\
\text { sub even available for all basic } \\
\text { understanding them. }\end{array}$ & 4.26 & 0.78 & 85.20 & $\begin{array}{l}\mathrm{Hig} \\
\mathrm{h}\end{array}$ & 6 \\
\hline 7 & $\begin{array}{l}\text { The bank's } \\
\text { management segmenting the } \\
\text { overall objectives of the sub- } \\
\text { goals are derived from the overall }\end{array}$ & 4.26 & 0.78 & 85.20 & $\begin{array}{l}\text { Hig } \\
\mathrm{h}\end{array}$ & 6 \\
\hline
\end{tabular}


The Importance of (COSO-ERM) Model Implementation .......

\begin{tabular}{|c|c|c|c|c|c|c|}
\hline & $\begin{array}{lll}\text { objectives and each } & \text { stage } & \text { of } \\
\text { the work } & & \end{array}$ & & & & & \\
\hline 8 & $\begin{array}{l}\text { Effective risk management in the } \\
\text { bank considered a guarantee } \\
\text { appropriate to achieve operational } \\
\text { objectives, reporting and } \\
\text { compliance in the bank }\end{array}$ & 4.24 & 0.80 & 84.80 & $\begin{array}{l}\text { Hig } \\
\mathrm{h}\end{array}$ & 8 \\
\hline & Average & 4.38 & 0.50 & 87.60 & $\begin{array}{l}\text { Hig } \\
\mathrm{h}\end{array}$ & \\
\hline
\end{tabular}

Table (14): Means, standard deviation for Events Identification Component COSO- ERM model (in descending order)

\begin{tabular}{|l|l|l|l|l|l|l|}
\hline No. & Paragraph & $\begin{array}{l}\text { Mea } \\
\text { n }\end{array}$ & $\begin{array}{l}\text { Importan } \\
\text { ce \% }\end{array}$ & $\begin{array}{l}\text { Standar } \\
\mathbf{d} \\
\text { deviatio } \\
\text { n }\end{array}$ & $\begin{array}{l}\text { lev } \\
\text { el }\end{array}$ & $\begin{array}{l}\text { Ran } \\
\text { k }\end{array}$ \\
\hline & $\begin{array}{l}\text { By management to identify } \\
\text { the likely occurrence and } \\
\text { classification of events that } \\
\text { may have a negative impact on } \\
\text { the bank's ability to achieve the } \\
\text { goals and strategic }\end{array}$ & 4.59 & 0.50 & 91.80 & $\begin{array}{l}\text { Hig } \\
\text { h }\end{array}$ & 1 \\
\hline $\begin{array}{l}\text { When identifying events manageme } \\
\text { nt } \\
\text { takes into account the internal and } \\
\text { external risks that affect the } \\
\text { achievement of goals }\end{array}$ & 4.41 & 0.56 & 88.20 & $\begin{array}{l}\text { Hig } \\
\text { h }\end{array}$ & 2 \\
\hline Average & 4.5 & 0.43 & 90.00 & $\begin{array}{l}\text { Hig } \\
\text { h }\end{array}$ & \\
\hline
\end{tabular}

Table (15): Means, standard deviation for Risk Assessment Component COSO- ERM model (in descending order)

\begin{tabular}{|l|l|l|l|l|l|l|}
\hline No. & Paragraph & $\begin{array}{l}\text { Mea } \\
\mathbf{n}\end{array}$ & $\begin{array}{l}\text { Importan } \\
\text { ce\% }\end{array}$ & $\begin{array}{l}\text { Standar } \\
\mathbf{d} \\
\text { deviatio } \\
\mathbf{n}\end{array}$ & $\begin{array}{l}\text { lev } \\
\text { el }\end{array}$ & $\begin{array}{l}\text { Ran } \\
\mathbf{k}\end{array}$ \\
\hline 8 & $\begin{array}{l}\text { The Audit Committee report to the } \\
\text { board regarding the risks and the } \\
\text { changes that may have an } \\
\text { impact on } \\
\text { the bank }\end{array}$ & 4.53 & 0.57 & 90.60 & $\begin{array}{l}\text { Hig } \\
\mathrm{h}\end{array}$ & 1 \\
\hline 5 & $\begin{array}{l}\text { The risks are on the level of all } \\
\text { operational activities evaluated. }\end{array}$ & 4.5 & 0.66 & 90.00 & $\begin{array}{l}\text { Hig } \\
\mathrm{h}\end{array}$ & 2 \\
\hline 6 & $\begin{array}{l}\text { The bank's management to risk } \\
\text { assessment as part of the design } \\
\text { of the internal control system and } \\
\text { turn it to reduce errors and } \\
\text { irregularities }\end{array}$ & 4.41 & 0.65 & 88.20 & $\mathrm{Hig}$ \\
$\mathrm{h}$ & 3 \\
\hline
\end{tabular}




\begin{tabular}{|l|l|l|l|l|l|l|}
\hline 3 & $\begin{array}{l}\text { The Executive Directors or the } \\
\text { Audit Committe or risk } \\
\text { management to identify risks that } \\
\text { can be controlled and those } \\
\text { risks are not subject to control. }\end{array}$ & 4.36 & 0.58 & 87.20 & $\begin{array}{l}\text { Hig } \\
\mathrm{h}\end{array}$ & 4 \\
\hline 7 & $\begin{array}{l}\text { The Bank has appropriate and a } \\
\text { variety of mechanisms for risk } \\
\text { assessment }\end{array}$ & 4.34 & 0.58 & 86.80 & $\begin{array}{l}\text { Hig } \\
\mathrm{h}\end{array}$ & 5 \\
\hline 1 & $\begin{array}{l}\text { The Executive Directors or the } \\
\text { Audit Committee or management } \\
\text { determines the risk of internal and } \\
\text { external risk and expected }\end{array}$ & 4.29 & 0.73 & 85.80 & $\begin{array}{l}\mathrm{Hig} \\
\mathrm{h}\end{array}$ & 6 \\
\hline 4 & $\begin{array}{l}\text { The Executive Directors or the } \\
\text { Audit Committee's risk } \\
\text { management or risk } \\
\text { assessment periodically. }\end{array}$ & 4.28 & 0.67 & 85.60 & $\begin{array}{l}\mathrm{Hig} \\
\mathrm{h}\end{array}$ & 7 \\
\hline $\begin{array}{l}\text { The Executive Directors or the } \\
\text { Audit Committee or Risk } \\
\text { Management classifies all kinds } \\
\text { of risks and evaluated in terms } \\
\text { of its impact on the banking } \\
\text { activities and to achieve its goals. }\end{array}$ & 4.12 & 0.65 & 82.40 & $\begin{array}{l}\mathrm{Hig} \\
\mathrm{h}\end{array}$ & 8 \\
\hline Average & 4.36 & 0.42 & 87.20 & $\begin{array}{l}\mathrm{Hig} \\
\mathrm{h}\end{array}$ \\
\hline
\end{tabular}

Table (16): Means, standard deviation for Risk Response Component COSO- ERM model (in descending order)

\begin{tabular}{|c|c|c|c|c|c|c|}
\hline No. & Paragraph & $\begin{array}{l}\text { Mea } \\
\text { n }\end{array}$ & $\begin{array}{l}\text { Importan } \\
\text { ce } \\
\%\end{array}$ & $\begin{array}{l}\text { Standar } \\
\text { d } \\
\text { deviatio } \\
\text { n }\end{array}$ & level & $\begin{array}{l}\text { Ran } \\
\mathbf{k}\end{array}$ \\
\hline 3 & $\begin{array}{l}\text { It is updated budget for the } \\
\text { following year to reflect } \\
\text { the change } \\
\text { circumstances resulting in risk } \\
\text { during the year. }\end{array}$ & 4.34 & 0.83 & 86.80 & High & 1 \\
\hline 1 & $\begin{array}{l}\text { After the relevant risk } \\
\text { management determine how to } \\
\text { respond to this risk assessment. }\end{array}$ & 4.31 & 0.68 & 86.20 & High & 2 \\
\hline 2 & $\begin{array}{l}\text { The Executive Directors or the } \\
\text { Audit Committee or the risk } \\
\text { management measures } \\
\text { developed as quickly as } \\
\text { possible to cope with the risks }\end{array}$ & 4.28 & 0.74 & 85.60 & High & 3 \\
\hline & Average & 4.31 & 0.61 & 86.20 & High & \\
\hline
\end{tabular}


Table (17): Means, standard deviation for Control Activities Component COSO- ERM model (in descending order)

\begin{tabular}{|c|c|c|c|c|c|c|}
\hline No & Paragraph & $\begin{array}{l}\text { Me } \\
\text { an }\end{array}$ & $\begin{array}{l}\text { Importa } \\
\text { nce } \\
\%\end{array}$ & $\begin{array}{l}\text { Standa } \\
\text { rd } \\
\text { deviati } \\
\text { on }\end{array}$ & $\begin{array}{l}\text { lev } \\
\text { el }\end{array}$ & $\begin{array}{l}\text { Ran } \\
\mathbf{k}\end{array}$ \\
\hline 12 & $\begin{array}{l}\text { There must be at the } \\
\text { bank brochures systems } \\
\text { use either manual or electronic } \\
\text { (ie explain the use of the } \\
\text { systems) procedures }\end{array}$ & 4.45 & 0.80 & 89.00 & $\begin{array}{l}\text { Hig } \\
\mathrm{h}\end{array}$ & 1 \\
\hline 1 & $\begin{array}{l}\text { Regulatory activities are } \\
\text { the policies and } \\
\text { procedures that help ensure the } \\
\text { implementation of risk } \\
\text { management responses in the } \\
\text { bank. }\end{array}$ & 4.43 & 0.77 & 88.60 & $\begin{array}{l}\text { Hig } \\
\mathrm{h}\end{array}$ & 2 \\
\hline 11 & $\begin{array}{l}\text { It must be checked from financial } \\
\text { transactions } \\
\text { events before and after they } \\
\text { occur. }\end{array}$ & 4.4 & 0.84 & 88.00 & $\begin{array}{l}\text { Hig } \\
\mathrm{h}\end{array}$ & 3 \\
\hline 10 & $\begin{array}{l}\text { There must } \\
\text { be adequate separation between } \\
\text { the functions of the calculator } \\
\text { division, } \\
\text { includes (systems } \\
\text { programmer analyst, } \\
\text { operator calculator, a librarian). }\end{array}$ & 4.36 & 0.81 & 87.20 & $\begin{array}{l}\text { Hig } \\
\mathrm{h}\end{array}$ & 4 \\
\hline 2 & $\begin{array}{l}\text { Risk management in the bank to } \\
\text { consider regulatory activities as } \\
\text { an important part of the } \\
\text { process which seeks to } \\
\text { achieve business goals. }\end{array}$ & 4.31 & 0.63 & 86.20 & $\begin{array}{l}\text { Hig } \\
\mathrm{h}\end{array}$ & 5 \\
\hline 5 & $\begin{array}{lr}\text { It must be a review } & \text { of bank } \\
\text { policies } & \text { and } \\
\text { procedures periodically } & \text { to } \\
\text { determine whether } & \text { they } \\
\text { are still appropriate. } & \end{array}$ & 4.29 & 0.77 & 85.80 & $\begin{array}{l}\text { Hig } \\
\mathrm{h}\end{array}$ & 6 \\
\hline 9 & $\begin{array}{l}\text { There must be a physical control } \\
\text { over the use of assets and } \\
\text { records (i. e that the use of assets } \\
\text { and records is limited to } \\
\text { authorized personnel only). }\end{array}$ & 4.29 & 0.75 & 85.80 & $\begin{array}{l}\text { Hig } \\
\mathrm{h}\end{array}$ & 6 \\
\hline 4 & $\begin{array}{l}\text { The bank's } \\
\text { management should risk } \\
\text { assessment as a prerequisite for } \\
\text { determining control activities. }\end{array}$ & 4.28 & 0.70 & 85.60 & $\begin{array}{l}\text { Hig } \\
h\end{array}$ & 8 \\
\hline 13 & $\begin{array}{l}\text { The oversight activities into } \\
\text { practice in the bank confirms to }\end{array}$ & 4.21 & 0.77 & 84.20 & & 9 \\
\hline
\end{tabular}




\begin{tabular}{|c|c|c|c|c|c|c|}
\hline & $\begin{array}{l}\text { adhere to established policy and } \\
\text { Implementation of actions for } \\
\text { addressing the risks associated. }\end{array}$ & & & & $\begin{array}{l}\text { Hig } \\
\mathrm{h}\end{array}$ & \\
\hline 6 & $\begin{array}{l}\text { Control activities must be } \\
\text { specified within the } \\
\text { bank within four categories: } \\
\text { prevention, guidelines, verificatio } \\
\text { n, and corrective. }\end{array}$ & 4.17 & 0.82 & 83.40 & $\begin{array}{l}\text { Hig } \\
\text { h }\end{array}$ & 10 \\
\hline 7 & $\begin{array}{l}\text { The control include all aspects of } \\
\text { banking activity in the bank's } \\
\text { activities. }\end{array}$ & 4.17 & 0.75 & 83.40 & $\begin{array}{l}\text { Hig } \\
\text { h }\end{array}$ & 10 \\
\hline 3 & $\begin{array}{l}\text { Is } \\
\text { placed regulatory activities in ge } \\
\text { neral } \\
\text { to ensure that the risk response } \\
\text { appropriately and timely. }\end{array}$ & 4.14 & 0.87 & 82.80 & $\begin{array}{l}\text { Hig } \\
\text { h }\end{array}$ & 12 \\
\hline 8 & $\begin{array}{l}\text { There } \\
\text { be adequate separation } \\
\text { functions (mandate, operating, } D \\
\text { ate acquisition of } \\
\text { assets, traded, audited) }\end{array}$ & 4.14 & 0.89 & 82.80 & $\begin{array}{l}\text { Hig } \\
\text { h }\end{array}$ & 12 \\
\hline & Average & 4.28 & 0.55 & 85.60 & $\begin{array}{l}\text { Hig } \\
\mathrm{h}\end{array}$ & \\
\hline
\end{tabular}

Table (18): Means, standard deviation for Information \& Communications Component COSO- ERM model (in descending order)

\begin{tabular}{|c|c|c|c|c|c|c|}
\hline $\begin{array}{l}\text { No } \\
\text { • }\end{array}$ & Paragraph & $\begin{array}{l}\text { Me } \\
\text { an }\end{array}$ & $\begin{array}{l}\text { Importa } \\
\text { nce } \\
\%\end{array}$ & $\begin{array}{l}\text { Standa } \\
\text { rd } \\
\text { deviati } \\
\text { on }\end{array}$ & $\begin{array}{l}\text { lev } \\
\text { el }\end{array}$ & $\begin{array}{l}\text { Ra } \\
\text { nk }\end{array}$ \\
\hline 11 & $\begin{array}{l}\text { It must be connected } \\
\text { to violations to the responsible } \\
\text { authorities within } \\
\text { bank without the } \\
\text { the identity disclosing } \\
\text { person reported as irregularities. }\end{array}$ & 4.5 & 0.78 & 90.00 & $\begin{array}{l}\mathrm{Hi} \\
\text { gh }\end{array}$ & 1 \\
\hline 13 & $\begin{array}{l}\text { There is a } \\
\text { need to devise methods of } \\
\text { communication to employees for } \\
\text { reporting relevant risk to the } \\
\text { Supreme managers of the bank }\end{array}$ & 4.48 & 0.63 & 89.60 & $\begin{array}{l}\mathrm{Hi} \\
\text { gh }\end{array}$ & 2 \\
\hline 3 & $\begin{array}{l}\text { Should identify } \\
\text { relevant information and keep } \\
\text { them and reported in the form } \\
\text { of a time frame can staff to carry }\end{array}$ & 4.43 & 0.57 & 88.60 & $\mathrm{Hi}$ & 3 \\
\hline
\end{tabular}




\begin{tabular}{|c|c|c|c|c|c|c|}
\hline & $\begin{array}{l}\text { out their responsibilities and } \\
\text { effective communication with } \\
\text { them as well, where it } \\
\text { should flow through all parts } \\
\text { of the bank. }\end{array}$ & & & & gh & \\
\hline 1 & $\begin{array}{l}\text { There are information systems in } \\
\text { the bank includes all } \\
\text { the financial and non-financial } \\
\text { information regarding } \\
\text { suspension of internal and } \\
\text { external events to stroll the } \\
\text { realization of the bank and make } \\
\text { decisions. }\end{array}$ & 4.41 & 0.62 & 88.20 & $\begin{array}{l}\mathrm{Hi} \\
\mathrm{gh}\end{array}$ & 4 \\
\hline 4 & $\begin{array}{l}\text { There must be suitable polices } \\
\text { for modification and } \\
\text { development of accounting } \\
\text { information and } \\
\begin{array}{l}\text { systems and controls } \\
\text { face risks in banks. }\end{array}\end{array}$ & 4.38 & 0.72 & 87.60 & $\begin{array}{l}\mathrm{Hi} \\
\mathrm{gh}\end{array}$ & 5 \\
\hline 5 & $\begin{array}{l}\text { There must be effective control } \\
\text { of information systems to reduce } \\
\text { risk. }\end{array}$ & 4.38 & 0.62 & 87.60 & $\begin{array}{l}\mathrm{Hi} \\
\mathrm{gh}\end{array}$ & 5 \\
\hline 12 & $\begin{array}{l}\begin{array}{l}\text { The bank should respond to the } \\
\text { connections } \\
\text { of third } \\
\text { parties (customers, suppliers, } \\
\text { government agencies) } \\
\text { properly and in a timely manner. }\end{array}\end{array}$ & 4.38 & 0.70 & 87.60 & $\begin{array}{l}\mathrm{Hi} \\
\mathrm{gh}\end{array}$ & 5 \\
\hline 6 & $\begin{array}{l}\text { Should the Bank has adequate } \\
\text { and effective lines of } \\
\text { communication deals } \\
\text { throughout the bank }\end{array}$ & 4.36 & 0.61 & 87.20 & $\begin{array}{l}\mathrm{Hi} \\
\mathrm{gh}\end{array}$ & 8 \\
\hline 2 & $\begin{array}{l}\text { The development of information } \\
\text { systems on the basis of the } \\
\text { development of plans to cope } \\
\text { with risks. }\end{array}$ & 4.34 & 0.66 & 86.80 & $\begin{array}{l}\mathrm{Hi} \\
\mathrm{gh}\end{array}$ & 9 \\
\hline 8 & $\begin{array}{l}\text { There } \\
\text { be open communication } \\
\text { channels between the bank's } \\
\text { management and staff so that } \\
\text { the staff of the delivery } \\
\text { of important information to } \\
\text { the management of all the risks } \\
\text { faced by }\end{array}$ & 4.33 & 0.63 & 86.60 & $\begin{array}{l}\mathrm{Hi} \\
\mathrm{gh}\end{array}$ & 10 \\
\hline 9 & $\begin{array}{l}\text { It must be reported to the } \\
\text { supervisory staff controls and } \\
\text { how to deal with it and } \\
\text { responsibility for compliance. }\end{array}$ & 4.31 & 0.71 & 86.20 & $\begin{array}{l}\mathrm{Hi} \\
\mathrm{gh}\end{array}$ & 11 \\
\hline 7 & $\begin{array}{l}\text { It must be communicated to the } \\
\text { staff regulations and laws across }\end{array}$ & 4.28 & 0.70 & 85.60 & & 12 \\
\hline
\end{tabular}




\begin{tabular}{|c|c|c|c|c|c|c|}
\hline & $\begin{array}{l}\text { the lines of communication as } \\
\text { well as the policies and } \\
\text { procedures established by the } \\
\text { bank's management. }\end{array}$ & & & & $\begin{array}{l}\mathrm{Hi} \\
\text { gh }\end{array}$ & \\
\hline 10 & $\begin{array}{l}\text { Having the right people with the } \\
\text { right information, at the right } \\
\text { time and the right place is a } \\
\text { must to influence } \\
\text { the management of risk in the } \\
\text { Bank }\end{array}$ & 4.24 & 0.80 & 84.80 & $\begin{array}{l}\mathrm{Hi} \\
\text { gh }\end{array}$ & 13 \\
\hline & Average & 4.37 & 0.41 & 87.40 & $\begin{array}{l}\mathrm{Hi} \\
\text { gh }\end{array}$ & \\
\hline
\end{tabular}

Table (19): Means, standard deviation for Monitoring Component COSO- ERM model (in descending order)

\begin{tabular}{|c|c|c|c|c|c|c|}
\hline $\begin{array}{l}\text { No } \\
.\end{array}$ & Paragraph & $\begin{array}{l}\text { Mea } \\
\text { n }\end{array}$ & $\begin{array}{l}\text { Importa } \\
\text { nce \% }\end{array}$ & $\begin{array}{l}\text { Standar } \\
\text { d } \\
\text { deviatio } \\
\text { n }\end{array}$ & $\begin{array}{l}\text { lev } \\
\text { el }\end{array}$ & $\begin{array}{l}\text { Ran } \\
\mathbf{k}\end{array}$ \\
\hline 6 & $\begin{array}{l}\text { The bank's } \\
\text { management continuously } \\
\text { monitors } \\
\text { the control components to } \\
\text { reach for excellence oversight. }\end{array}$ & 4.48 & 0.57 & 89.60 & $\begin{array}{l}\mathrm{Hi} \\
\text { gh }\end{array}$ & 1 \\
\hline 4 & $\begin{array}{l}\text { bank's management must take } \\
\text { appropriate action in a timely } \\
\text { manner to correct deficiencies } \\
\text { in the controls reported by the } \\
\text { Internal Auditor }\end{array}$ & 4.43 & 0.62 & 88.60 & $\begin{array}{l}\mathrm{Hi} \\
\text { gh }\end{array}$ & 2 \\
\hline 1 & $\begin{array}{l}\text { Authorities should monitor risk } \\
\text { management to assess } \\
\text { the performance of its } \\
\text { components over time, and this } \\
\text { can be achieved through } \\
\text { continuous monitoring of } \\
\text { activities and } \\
\text { separate evaluation or a } \\
\text { combination of both }\end{array}$ & 4.34 & 0.58 & 86.80 & $\begin{array}{l}\mathrm{Hi} \\
\mathrm{gh}\end{array}$ & 3 \\
\hline 2 & $\begin{array}{l}\text { The bank's management follow- } \\
\text { up process to determine the } \\
\text { extent of implementation of } \\
\text { control patch } \\
\text { and subject them to determine } \\
\text { whether adjusted in line with } \\
\text { the light conditions }\end{array}$ & 4.33 & 0.63 & 86.60 & $\begin{array}{l}\mathrm{Hi} \\
\mathrm{gh}\end{array}$ & 4 \\
\hline
\end{tabular}


The Importance of (COSO-ERM) Model Implementation ......

\begin{tabular}{|l|l|l|l|l|l|l|}
\hline 7 & $\begin{array}{l}\text { The bank's management to } \\
\text { issue a report on } \\
\text { the responsibility for designing } \\
\text { and maintaining an } \\
\text { effective internal control } \\
\text { system. }\end{array}$ \\
\hline 3 & $\begin{array}{l}\text { It is adjusted policies and } \\
\text { procedures in accordance with } \\
\text { the regulatory changes and the } \\
\text { required bank interest. }\end{array}$ & 4.28 & 0.70 & 85.75 & $\begin{array}{l}\mathrm{Hi} \\
\text { gh }\end{array}$ & 5 \\
\hline 5 & $\begin{array}{l}\text { Bank management must respon } \\
\text { d appropriately and a timely } \\
\text { manner to the results and } \\
\text { recommendations of } \\
\text { the External Auditor on } \\
\text { the internal control auditor. }\end{array}$ & 4.26 & 0.66 & 85.20 & $\begin{array}{l}\mathrm{Hi} \\
\text { gh }\end{array}$ & 7 \\
\hline & Average & 4.35 & 0.43 & 87.00 & $\begin{array}{l}\mathrm{Hi} \\
\text { gh }\end{array}$ \\
\hline
\end{tabular}

$\operatorname{xx} x x x x x x x x x x x x x$ 